\title{
Comparative Analysis of Three Proposed Federal Renewable Electricity Standards
}

Technical Report NREL/TP-6A2-45877

May 2009

Patrick Sullivan, Jeffrey Logan, Lori Bird, and Walter Short 


\section{Comparative Analysis of Three Proposed Federal Renewable Electricity Standards}

Technical Report NREL/TP-6A2-45877

May 2009

Patrick Sullivan, Jeffrey Logan, Lori Bird, and Walter Short

Prepared under Task No. SAO7.9C50

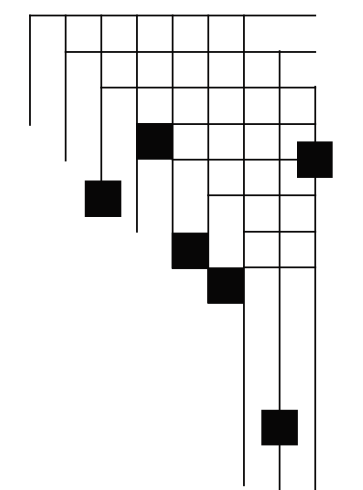

National Renewable Energy Laboratory

1617 Cole Boulevard, Golden, Colorado 80401-3393

303-275-3000 • www.nrel.gov

NREL is a national laboratory of the U.S. Department of Energy

Office of Energy Efficiency and Renewable Energy

Operated by the Alliance for Sustainable Energy, LLC

Contract No. DE-AC36-08-GO28308 


\section{NOTICE}

This report was prepared as an account of work sponsored by an agency of the United States government. Neither the United States government nor any agency thereof, nor any of their employees, makes any warranty, express or implied, or assumes any legal liability or responsibility for the accuracy, completeness, or usefulness of any information, apparatus, product, or process disclosed, or represents that its use would not infringe privately owned rights. Reference herein to any specific commercial product, process, or service by trade name, trademark, manufacturer, or otherwise does not necessarily constitute or imply its endorsement, recommendation, or favoring by the United States government or any agency thereof. The views and opinions of authors expressed herein do not necessarily state or reflect those of the United States government or any agency thereof.

Available electronically at http://www.osti.gov/bridge

Available for a processing fee to U.S. Department of Energy and its contractors, in paper, from:

U.S. Department of Energy

Office of Scientific and Technical Information

P.O. Box 62

Oak Ridge, TN 37831-0062

phone: 865.576 .8401

fax: 865.576 .5728

email: mailto:reports@adonis.osti.gov

Available for sale to the public, in paper, from:

U.S. Department of Commerce

National Technical Information Service

5285 Port Royal Road

Springfield, VA 22161

phone: 800.553 .6847

fax: 703.605.6900

email: orders@ntis.fedworld.gov

online ordering: http://www.ntis.gov/ordering.htm 


\section{Acknowledgments}

This work was funded by the U.S. Department of Energy's (DOE's) Office of Energy Efficiency and Renewable Energy (EERE). The authors would like to thank Doug Arent, Monisha Shah, and Ted James of the National Renewable Energy Laboratory (NREL) for their guidance and input. We also thank Ryan Wiser of the Lawrence Berkeley National Laboratory for providing helpful feedback. Special appreciation goes to Jeff Deyette of the Union of Concerned Scientists, Eliot Metzger of the World Resources Institute, and John Wilson of the Southern Alliance for Clean Energy for their reviews and input on revisions to the model. The authors also offer their thanks to Michelle Kubik in the NREL Technical Communications Office for providing editorial support. Any remaining errors or omissions are, of course, the responsibility of the authors. 


\section{Executive Summary}

This paper analyzes potential impacts of proposed national renewable electricity standard (RES) legislation. An RES is a mandate requiring certain electricity retailers to provide a minimum share of their electricity sales from qualifying renewable power generation. The analysis focuses on draft bills introduced individually by Senator Jeff Bingaman and Representative Edward Markey, and jointly by representatives Henry Waxman and Markey. ${ }^{1}$

We used NREL's Regional Energy Deployment System (ReEDS) model to evaluate the impacts of the proposed RES requirements on the U.S. energy sector in four scenarios:

- A base case where only currently enacted legislation is simulated

- A $20 \%$ by 2021 RES target, with $25 \%$ of the RES assumed to be met with qualifying energy efficiency projects (hereafter referred to as "Bingaman")

- A $25 \%$ by 2025 RES target, with no energy efficiency substitutions allowed (Markey)

- A $25 \%$ by 2025 RES target, with $20 \%$ of the RES assumed to be met by efficiency, and a cumulative 15\% reduction in load by 2020 (Waxman).

The fourth scenario considers the RES and the associated energy efficiency resource standard (EERS) independently of all other energy or climate measures in the Waxman discussion draft. No carbon policies are considered.

The Bingaman RES proposal analyzed here exempts small electricity providers and allows up to $25 \%$ of the RES targets to be met through qualifying energy efficiency projects annually. The Markey legislation exempts a smaller group of utilities from meeting the RES and does not allow the substitution of energy efficiency for renewable energy. The Waxman discussion draft calls for a 25\% renewable target by 2025 , with the same exemptions regarding utility size as in the Markey bill; however, Waxman allows states to reduce the annual RES targets by up to $20 \%$ if the state has met the EERS. The EERS is a separate, but linked, requirement in the bill, and mandates cumulative national electricity savings of $15 \%$ by 2020 .

Existing hydropower and municipal solid-waste generation resources do not qualify as eligible forms of renewable energy under any of the proposed RES bills, but are deducted from retail electricity providers' retail sales to calculate their renewable energy compliance obligations. In each of the proposed bills, the RES would allow affected electricity providers to use any combination of the following to achieve their target: 1) generate their own renewable energy, 2) purchase renewable energy certificates (RECs), or 3) pay an "alternative compliance payment," which serves as an effective safety-valve on the price of RECs. In each bill, distributed generators (such as rooftop photovoltaic (PV) systems) would earn triple credits for every kilowatt hour produced.

\footnotetext{
${ }^{1}$ This analysis updates an earlier, preliminary NREL investigation into the proposed Bingaman legislation that did not include changes mandated by the American Recovery and Reinvestment Act of 2009. In particular, it considers an extension of production tax credit through December 31, 2012. Available at http://www.nrel.gov/docs/fy09osti/45161.pdf.
} 
Each bill also aims to prevent preemption of, or interference with, existing state RES mandates that meet or exceed the federal requirement. Our analysis indicates that the current versions of the Markey and Waxman legislation may address REC market design issues more clearly than the Bingaman draft. Details are found in Section 5.

Findings are summarized in Table ES1:

Table ES1. Comparative Findings of the Proposed RES Legislation

\begin{tabular}{lcccc} 
& $\begin{array}{c}\text { Peak } \\
\text { Effective } \\
\text { RES (\%) }\end{array}$ & $\begin{array}{c}\text { Qualifying Renewable } \\
\text { Generation in 2030 } \\
(\text { TWh) }\end{array}$ & $\begin{array}{c}\text { Qualifying Renewable } \\
\text { Capacity in 2030 } \\
(\mathrm{GW})\end{array}$ & $\begin{array}{c}\mathrm{CO}_{2} \text { Emissions } \\
\text { Reductions in 2030 } \\
\text { (million metric tons) }\end{array}$ \\
\cline { 2 - 5 } Base & NA & 699 & 208 & NA \\
Case & 12.1 & 638 & 197 & 95 \\
Bingaman & 21.8 & 867 & 261 & 150 \\
Markey & 17.4 & 573 & 183 & 435 \\
Waxman & 17 & & &
\end{tabular}

- Effective RES. The Bingaman legislation has a nominal RES requirement of $20 \%$ in 2021 , but the effective renewable energy requirement is only $12.1 \%$ of total U.S. retail sales in that year. This conclusion is reached after considering the small-utility exemption and assuming that $25 \%$ of the target is met by fully using the energy efficiency compliance option. Hydropower and municipal solid waste generation, which are not counted toward the generation on which the RES is calculated, are subtracted later. For the Markey and Waxman bills, the effective renewable requirements are about $22 \%$ and $17 \%$, respectively, of total retail sales in 2025 .

- Resulting RE Increment Required. The base case scenario estimates that qualifying renewable generators will provide $10.4 \%$ of the national load in 2020 and $12.4 \%$ in 2024 (the model tracks only even-numbered years), due to a combination of existing state RES mandates, other existing incentives, and the forecasted, least-cost economics of electricity generation. The proposed Bingaman legislation would ostensibly require about an additional $2 \%$ of total load to be met with qualifying renewables by 2021 beyond the assumed base case. However, the triple credits granted to generation from distributed PV satisfy the Bingaman RES requirements with less than $10 \%$ of total generation coming from qualified renewable sources. Thus, this analysis indicates a slight reduction in energy generated from renewables in the Bingaman case compared to the base case; this is due to the triple credits applied to distributed PV and the reduction in load due to energy efficiency options. ${ }^{2}$ The Markey legislation would require about $10 \%$ more load to be met by generation from qualifying renewables beyond the base case scenario by 2025 , while the Waxman bill would require renewable sources to meet an additional $5 \%$ of total load.

- Impact on Capacity. Qualifying renewable energy capacity reaches approximately 208 gigawatts $(\mathrm{GW})$ in 2030 in the base case. In comparison, the Bingaman, Markey, and Waxman cases result in 197, 261, and $183 \mathrm{GW}$ of renewables in 2030,

\footnotetext{
${ }^{2}$ If a system is required to have $12 \%$ renewable generation but grants triple credits to distributed PV, that system could, for instance, meet the requirement with only $10 \%$ renewable generation if $1 \%$ of generation is from distributed PV. The $9 \%$ from central renewable plus 3 times $1 \%$ from distributed equals $12 \%$.
} 
respectively. Renewable capacity in the Bingaman scenario is less than that in the base case for two reasons. First, the assumption about energy efficiency in this scenario reduces electricity demand significantly, and thus the need for renewable contributions. Second, this analysis used an external forecast of PV deployment from a 2009 study by the Union of Concerned Scientists. The exogenously calculated PV penetration in all three RES scenarios is higher than in the base case, and thus further reduces the need for other renewable options to contribute. These reasons also apply to the Waxman scenario, which forecasts renewable capacity very close to that in the Bingaman case.

- Impact on Emissions. The Bingaman RES results in a modest 95 million metric ton (MMT) annual reduction in carbon dioxide $\left(\mathrm{CO}_{2}\right)$ emissions in 2030 compared to the base case. Most of this reduction is due to efficiency savings rather than expanded use of renewable energy. The Markey RES saves an estimated 150 MMT per year in 2030, exclusively from expanded renewable energy use. The Waxman scenario reduces annual carbon dioxide emissions in 2030 by 435 MMT, most of which is due to the assumed $15 \%$ reduction in power demand compared to the baseline.

- Importance of Transmission. All results noted here assume that transmission capacity is built as required for both transporting electricity and maintaining system reliability. Results would differ if construction of transmission is delayed.

- Regional Results. Western states, endowed with wind and solar resources, exceed their RES requirements based on renewable energy deliveries; states in the Southeast generally rely on biomass co-firing and purchasing RECs.

- Impact on Prices. None of the RES bills modeled have a significant impact on consumer electricity prices at the national level. Differences between average national electricity prices in the RES cases and the base case are less than $1 \%$, according to the assumptions used in the modeling. The prices calculated in the Waxman scenario are significantly less than the base case, although our analysis did not consider the costs involved in implementing the EERS. In the Markey scenario, more states see a decline in calculated electricity prices than an increase, and no state sees an increase of more than $5 \%$ compared to the base case in 2022, the year of peak impact on prices. Estimated national REC prices peak in 2022 in the Waxman RES case at just less than $\$ 25 / \mathrm{MWh}$, while they reach about $\$ 15 / \mathrm{MWh}$ in the Markey case. 


\section{Table of Contents}

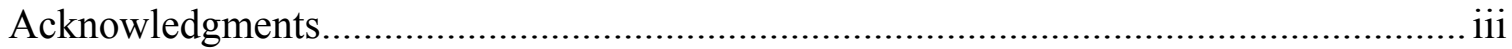

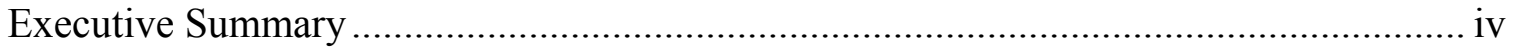

Table of Contents ....................................................................................................... vii

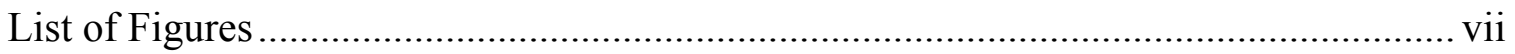

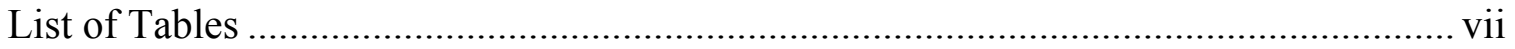

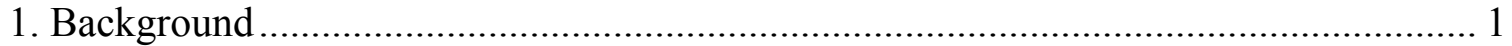

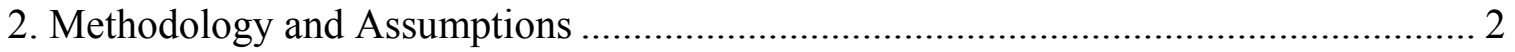

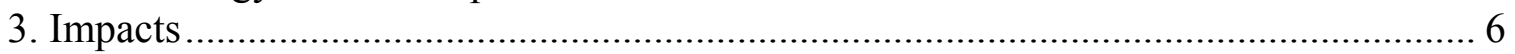

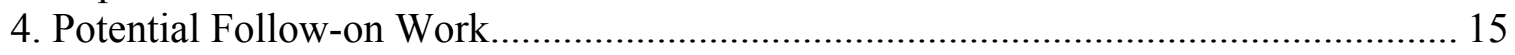

5. REC Market Design Issues in the Proposed RES Legislation................................... 16

Appendix A - Attributes of Modeling Renewable Electricity: ReEDS vs. NEMS ......... 20

Appendix B - State-Level 2030 Renewable Generation Totals from Markey Scenario (TWh)

\section{List of Figures}

Figure 1. Levelized cost of electricity inputs used in ReEDS ...................................... 5

Figure 2. Electricity-generating capacity by technology in the base case ....................... 7

Figure 3. Electricity generation by technology in the base case .................................. 7

Figure 4. Generating capacity and electricity generation in 2030 in each of the scenarios 8

Figure 5. Cumulative and annual installations of wind power .................................... 10

Figure 6. Annual and cumulative changes in $\mathrm{CO}_{2}$ emissions among the scenarios ......... 11

Figure 7. Preliminary assessment of RES on average national electricity prices............ 12

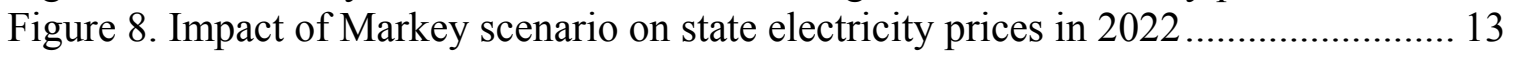

Figure 9. Simulated national price of renewable energy credits................................... 13

\section{List of Tables}

Table 1. Main Provisions of the Three RES Bills............................................................ 2

Table 2. PV Deployment Forecast in the RES Scenarios (GW) .................................... 4

Table 3. Comparative Requirements of the Proposed RES Legislation ............................ 6

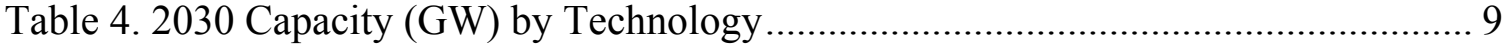

Table 5. Key Differences in REC Market Issues in the Three Proposed RES Bills......... 16 


\section{Background}

A renewable electricity standard (RES) — also referred to as a renewable portfolio standard (RPS) - requires certain electricity retailers to provide a minimum specified share of their total electricity sales from qualifying renewable power generation. ${ }^{3}$ RES policies can incorporate market-based mechanisms that enable obligated entities to buy or sell tradable renewable energy certificates (RECs) to demonstrate compliance. Many economists contend that the flexibility introduced in market-based trading systems lowers the overall cost in meeting the goal of expanded renewable energy use.

At the beginning of 2009, 28 states had RES mandates and an additional five had goals for renewable energy deployment. ${ }^{4}$ The U.S. Congress has considered a national RES since the $105^{\text {th }}$ session (1997-1999): the Senate has passed legislation three times, and the House once. To date, however, both houses have not acted in unison to pass legislation. ${ }^{5}$ While many in Congress support a national RES because of its perceived benefits for resource diversity, price stability, and environmental quality, others are concerned that it could lead to higher consumer costs and differentiated regional impacts.

In late January 2009, Senator Jeff Bingaman released a draft discussion document proposing a $20 \%$ RES by $2021 .^{6}$ The following week, Representative Edward Markey sponsored RES legislation in the House, ${ }^{7}$ calling for $25 \%$ renewable electricity by 2025 . On the same day, he released separate legislation designed to provide cumulative national electricity savings of $15 \%$ by $2020 .{ }^{8}$ One week later, Senator Tom Udall of New Mexico sponsored legislation with targets similar to the Markey RES bill; that legislation is not analyzed in this paper. ${ }^{9}$ Finally, in late March, representatives Waxman and Markey released the American Clean Energy and Security Act discussion draft, which included a modified version of the Markey RES, a utility energy efficiency resource standard (EERS), a cap-and-trade title, and other clean energy provisions. ${ }^{10}$

\footnotetext{
${ }^{3}$ For more background on existing state RES policies in the United States, see R. Wiser and G. Barbose, "Renewable Portfolio Standards in the United States: A Status Report with Data Through 2007," Lawrence Berkeley National Laboratory, April 2008; and D. Hurlbut, "State Clean Energy Practices: Renewable Portfolio Standards,” National Renewable Energy Laboratory, July 2008.

${ }^{4}$ The District of Columbia also has a mandated RES. The classification of state RES programs into mandatory or voluntary groupings can be debated. A map summarizing state RES mandatory and voluntary programs is available on the DSIRE Web site at http://www.dsireusa.org.

${ }^{5}$ For a history of RES legislation in the House and Senate, see F. Sissine, "Renewable Energy Portfolio Standard (RES): Background and Debate over a National Standard," Congressional Research Service, December 5, 2007.

${ }^{6}$ At the time of this writing, Senator Bingaman's discussion draft had not been given a bill number.

${ }^{7}$ H.R. 890, the American Renewable Energy Act.

${ }^{8}$ H.R. 889, the Save America Energy Act.

${ }^{9}$ The Udall bill (S. 433) offers voluntary exemptions to municipal, cooperative, state, and federal utilities, and could thus result in lower deployment of renewable energy than the Markey legislation despite many other similarities.

${ }^{10}$ More information on the discussion draft is available on the House Web site at http://energycommerce.house.gov/index.php?option $=$ com_content\&task=view\&id=1560\&Itemid=1
} 
This analysis considers the three proposed RES bills compared to a base case scenario. It does not simulate the impact of the cap-and-trade provision in the Waxman proposal in combination with the RES.

Table 1 summarizes the main provisions of the three RES bills analyzed. Section 5 highlights other important differences among the REC trading markets established by the bills.

Table 1. Main Provisions of the Three RES Bills

\begin{tabular}{|c|c|c|c|}
\hline Issue & Bingaman & Markey & Waxman \\
\hline RES Target & $\begin{array}{l}4 \% \text { by } 2011,20 \% \text { by } 2021 \\
\text { (through } 2039 \text { ) }\end{array}$ & $\begin{array}{l}6 \% \text { by } 2012,25 \% \text { by } \\
2025 \text { (through } 2040 \text { ) }\end{array}$ & Same as Markey \\
\hline Covered Entities & $\begin{array}{l}\text { All suppliers selling more than } \\
4 \text { million MWh (except in } \\
\text { Hawaii) }\end{array}$ & $\begin{array}{l}\text { All suppliers selling more } \\
\text { than } 1 \text { million } \mathrm{MWh}\end{array}$ & Same as Markey \\
\hline $\begin{array}{l}\text { "Existing" vs. } \\
\text { "New" Renewables }\end{array}$ & $\begin{array}{l}\text { RECs for existing renewables } \\
\text { (before } 1 / 1 / 2006) \text { cannot be } \\
\text { traded }\end{array}$ & No distinction & No distinction \\
\hline $\begin{array}{l}\text { Energy Efficiency } \\
\text { Allowed? }\end{array}$ & $\begin{array}{l}\text { Yes - EE can be used to meet } \\
\text { up to } 25 \% \text { of target each year }\end{array}$ & $\begin{array}{l}\text { No - Markey proposes an } \\
\text { independent EERS in a } \\
\text { separate bill (H.R. 889) }\end{array}$ & $\begin{array}{l}\text { Yes - States may } \\
\text { petition to reduce } \\
\text { annual obligation by up } \\
\text { to } 20 \% \text { if utilities } \\
\text { comply with separate } \\
\text { EERS }\end{array}$ \\
\hline Credit Multipliers & $\begin{array}{l}\text { Two federal RECs/kWh for } \\
\text { projects on tribal lands; three } \\
\text { RECs/kWh for distributed } \\
\text { generation (at "customer site," } \\
\text { 1MW limit) }\end{array}$ & $\begin{array}{l}\text { Three federal RECs/kWh } \\
\text { from distributed } \\
\text { generation sources (non- } \\
\text { combustion projects "at or } \\
\text { near" customer site, up to } \\
2 \mathrm{MW} \text { ) }\end{array}$ & Same as Markey \\
\hline
\end{tabular}

\section{Methodology and Assumptions}

The Regional Energy Deployment System (ReEDS) model, the capacity expansion and dispatch tool used for this analysis, was created to compare national electricity policy scenarios; it also has built-in capabilities for modeling an RES policy. An overview of ReEDS is provided in the text box on the following page. ${ }^{11}$

To appropriately model the proposed RES scenarios in ReEDS, the following assumptions were made. First, the target RES - which reaches 20\% from 2021 to 2039 in the Bingaman bill and 25\% from 2025 to 2039 in the Markey and Waxman bills-was prorated to $17 \%, 22 \%$, and $22 \%$, respectively, because small electric suppliers are exempted from the proposed requirements.

\footnotetext{
${ }^{11}$ A more detailed summary of the ReEDS methodology is found in Appendix A of the earlier NREL report on the proposed Bingaman RES, available at http://www.nrel.gov/docs/fy09osti/45161.pdf. Appendix A of this report compares and contrasts ReEDS with the U.S. Department of Energy's Energy Information Administration's (EIA) NEMS model.
} 
Second, in the Bingaman scenario, all balancing areas were assumed to use their full efficiency allowance ( $25 \%$ of the RES), because efficiency measures are usually more cost-effective than adding renewable power supply. ${ }^{12}$ In Waxman, the analysis assumes that all obligated entities meet the EERS, and that states petition to have the RES targets reduced by $20 \%$. These efficiency substitutions further reduced the effective RES to about 12\% of total U.S. retail sales in Bingaman from 2021 to 2039, and 17\% in Waxman from 2025 to 2040. The effective RES is the minimum amount of renewable power that would be required; in reality, not all states would necessarily use the entire efficiency allowance or allow their excess RECs used for meeting state RES obligations to count toward the federal obligation. The efficiency assumptions in both cases simplify what the legislation actually proposes and serve to identify one outer range where all efficiency substitutions are fully used. ${ }^{13}$

\section{Overview of the ReEDS Model}

NREL developed the Regional Energy Deployment System (ReEDS) model to analyze energy and climate policy options in the U.S. electricity sector. ReEDS is a linear programming model that simulates the least-cost expansion of electricity generation capacity and transmission, with detailed treatment of renewable electric options. ReEDS minimizes the system-wide cost of meeting forecasted electric loads, reserve requirements, and emission constraints by building and operating new generators and transmission in 22 two-year increments from 2006 to 2050.

ReEDS is unique in its ability to simulate access to and cost of transmission, access to and quality of renewable resources, the variability of wind and solar power, and the impact of variability on the reliability of the grid. ReEDS addresses these issues through a highly discretized regional structure (356 resource areas), explicit accounting for the variability in wind and solar output over time, and consideration of ancillary services requirements and costs.

ReEDS simulates "feedback" effects in the electricity market resulting from changes in demand, including how greater or lesser use of renewables might impact the price of fossil fuels used in power generation.

Technologies that contribute to the RES include wind, concentrated solar power (CSP), geothermal, biopower, ${ }^{14}$ and distributed photovoltaics (PV). As designated in the proposed legislation, existing hydropower and municipal solid waste are not counted, although both are subtracted from the generation on which the RES target is applied (the denominator). Also similar to the proposed legislation, distributed renewable energy systems are permitted to claim triple credits toward the RES (i.e., $1 \mathrm{kWh}$ from a rooftop $\mathrm{PV}$ system counts as $3 \mathrm{kWh}$ for RES accounting purposes). PV is the only eligible distributed renewable technology considered in this analysis.

\footnotetext{
${ }^{12}$ This simplification was assumed because ReEDS does not explicitly represent efficiency savings.

${ }^{13}$ In a recent report, the EIA analyzed the impacts of the Waxman bill by assuming full use of the efficiency substitution in one scenario and no use of the substitution in another. That study is available at http://www.eia.doe.gov/oiaf/servicerpt/acesa/index.html. Demand growth projections in ReEDS are taken from the EIA's Annual Energy Outlook 2009 (AEO 2009) projections.

${ }^{14}$ This includes both dedicated biomass generation and biomass co-firing at coal plants.
} 
Because ReEDS cannot analyze distributed technologies with the same rigor as it does utility installations, the expansion of distributed PV in the scenarios is guided by an exogenous projection at the North American Electric Reliability Corporation (NERC) region/subregion level. Table 2 shows these estimates, which come from a recent study by the Union of Concerned Scientists (UCS). ${ }^{15}$ There are three separate deployment forecasts: one for the base case, one for Bingaman, and one for Markey and Waxman. With recent and projected reductions in the price of photovoltaics, these market penetration estimates are particularly uncertain.

Table 2. PV Deployment Forecast in the RES Scenarios (GW)

\begin{tabular}{lrrrrr} 
& 2010 & 2020 & 2030 & 2040 & 2050 \\
\hline Base & 2.5 & 18 & 25 & 36 & 52 \\
Bingaman & 2.5 & 21 & 31 & 45 & 65 \\
Markey and Waxman & 2.5 & 19 & 39 & 57 & 83
\end{tabular}

This analysis applies the selected RES to the nation as a whole, and assumes that states, regions, or individual utilities purchase RECs to meet local shortfalls. If the entire country falls short of the RES, the analysis assesses an alternative compliance payment (see Section 5). The RES constraint, being only a national one, carries an implicit assumption that the REC market is frictionless-i.e., there is no transaction cost in the exchange of RECs. Thus, if it is cheaper for a region to purchase RECs through the market rather than build its own renewable generators or contract for renewable energy, it will do so.

There are other assumptions that are not specific to this analysis but can significantly affect the results and are, therefore, worth mentioning.

- Technology cost and performance parameters and projections are from Black and Veatch as estimated for the $20 \%$ Wind Energy by $2030^{16}$ study (see Figure 1).

- Fuel cost projections are from the Energy Information Administration (EIA) Annual Energy Outlook (AEO) 2009 reference case. The price of natural gas, in particular, can have a large impact on both investment and dispatch decisions in the model.

- Wind and other qualifying renewable electricity generators receive a production tax credit (PTC) of 2.1 cents per kilowatt hour (in 2008\$) through 2012; qualifying non-wind renewables receive the credit through 2013.

- CSP and distributed PV receive an investment tax credit (ITC) of $30 \%$ through 2016, after which it drops to $10 \%$.

- Nuclear capital costs have been multiplied by 1.5 from the Black and Veatch projections (i.e., from roughly $\$ 3,000 / \mathrm{kW}$ to $\$ 4,500 / \mathrm{kW}$ ) to better represent recently publicized cost-estimate increases and the current social political climate of uncertainty toward the technology.

\footnotetext{
${ }^{15}$ Union of Concerned Scientists, “Clean Energy, Green Jobs,” March 23, 2009. The UCS analysis used a modified version of the EIA’s National Energy Modeling System (NEMS).

http://www.ucsusa.org/clean_energy/solutions/renewable_energy_solutions/clean-energy-green-jobs.html

${ }^{16}$ U.S. Department of Energy, 20\% Wind Energy by 2030: Increasing Wind Energy's Contribution to U.S.

Electricity Supply, July 2008. http://www1.eere.energy.gov/windandhydro/pdfs/41869.pdf
} 
Technology Cost

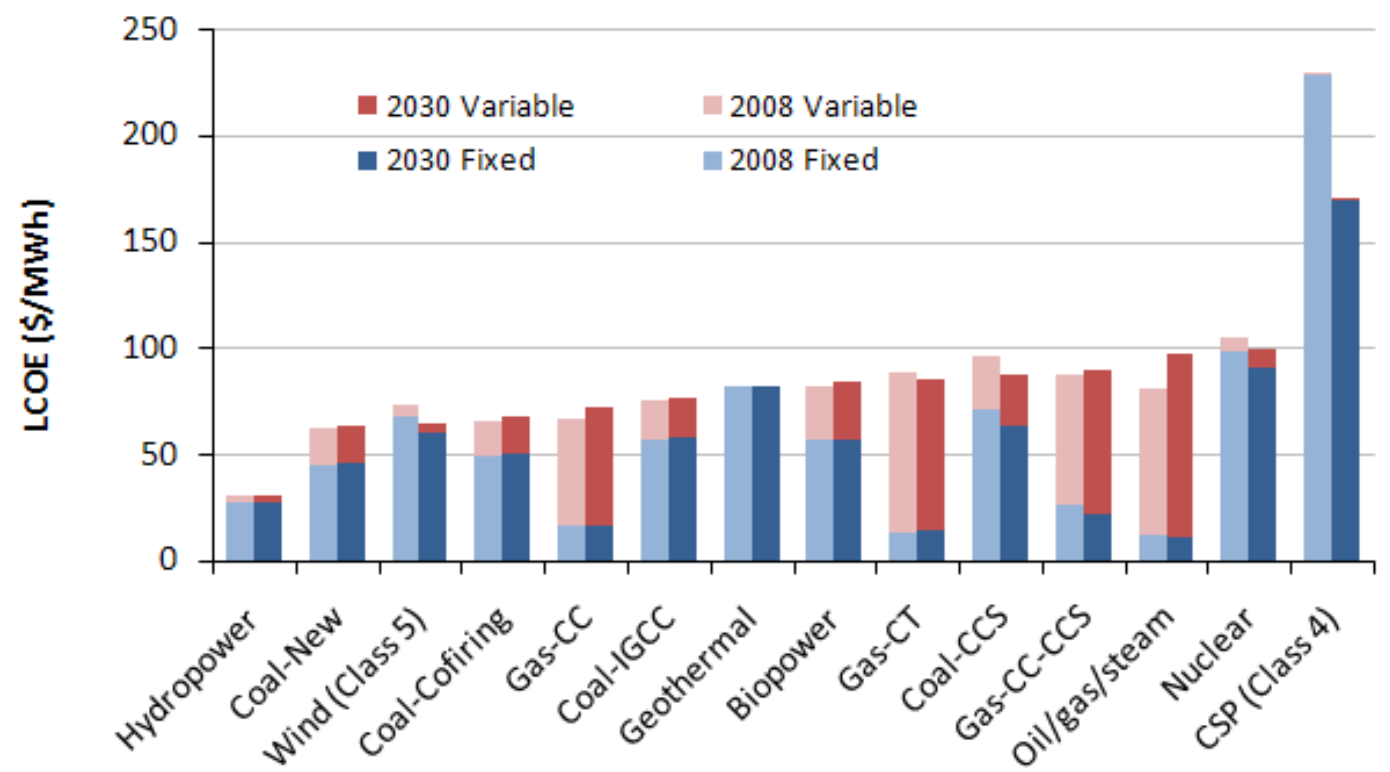

Figure 1. Levelized cost of electricity inputs used in ReEDS

- Load growth rates are defined by NERC region/subregion from the EIA AEO 2009 reference case, and seasonal and diurnal load curves are from Platts, an energy information service.

- There is no price, cap, or tax of any kind on $\mathrm{CO}_{2}$ or other greenhouse gases; sulfur dioxide $\left(\mathrm{SO}_{2}\right)$ is subject to the Clean Air Interstate Rule caps.

- All existing state-level RES targets with enforceable penalties are met in the baseline case. Most state RES programs ramp up renewable requirements through 2020 or 2025 before leveling off. ${ }^{17}$

- The analysis explicitly accounts for the cost of new transmission for all power generation options by determining when new transmission lines are needed and including the cost of building them.

- Other assumptions are outlined in the $20 \%$ Wind Energy by 2030 study.

Although the above inputs and assumptions have been vetted, some aspects of the future most likely will differ from the projections made in the model. In particular, political momentum to restrict carbon dioxide emissions will likely result in relatively higher costs for carbon-intensive generation sources that are not currently reflected in any of the scenarios. Additionally, recent changes in commodity pricing and other factors have led to changes in capital costs for most power generation technologies that differ from those established by Black and Veatch, and the current financial crisis has short-term implications for the cost of financing. Because this analysis focuses out to 2030, we have not accounted for these short-term perturbations.

${ }^{17}$ See the DSIRE database for information on specific state RES mandates (www.dsireusa.org). 
This analysis is based on optimizing least-cost expansion of the U.S. electricity sector. To be more specific, the result of a ReEDS scenario is the distribution of capacity expansion and dispatch that satisfies all of the required constraints (i.e., the system must reliably meet all load requirements and contingencies while satisfying emission laws, renewable standards, or other policy requirements) with the lowest cost for the overall system. Furthermore, as the model optimizes for least cost over the electric sector, these results are in no way indicative of the potential future make-up of the electric sector including factors such as job creation, economic development, or water availability and use. Despite the limitations outlined here, ReEDS provides a useful picture of how the electricity sector might develop during the next several decades under various policy scenarios.

\section{Impacts}

We simulated four scenarios in this analysis: a business-as-usual case, a Bingaman RES case, a Markey RES case, and a Waxman RES case. The scenarios will be referred to here as "base," "Bingaman," "Markey," and "Waxman."

Table 3 shows the parameters that drive the base case and scenarios. In some instances, the figures in the "actual renewable generation" column are lower than the "required renewable generation" column because distributed renewable generation gets triple compliance credit. In the Waxman scenario, for example, there are 57 terawatt hours (TWh) of distributed PV generation in 2030, so tripling this value would increase actual renewable generation from $573 \mathrm{TWh}$ to $687 \mathrm{TWh}$, thus satisfying the RES requirement. Additionally, the entries in the "eligible load" column include feedback effects of electricity prices on demand. The eligible load in the Markey case, for example, is higher than the base case because lower electricity prices in that scenario during the 2020 decade induce slightly higher electricity demand.

Table 3. Comparative Requirements of the Proposed RES Legislation

\begin{tabular}{lcccc} 
2030 Eligible & $\begin{array}{c}\text { Effective } \\
\text { Load (TWh) }\end{array}$ & $\begin{array}{c}\text { Required Renewable } \\
\text { RES (\%) }\end{array}$ & $\begin{array}{c}\text { Actual 2030 } \\
\text { Generation in 2030 (TWh) }\end{array}$ & $\begin{array}{c}\text { Rewle Generation } \\
\text { (TWh) }\end{array}$ \\
\cline { 2 - 5 } Base & 4505 & 0 & 0 & 699 \\
Bingaman & 4314 & 12.1 & 520 & 638 \\
Markey & 4510 & 21.8 & 981 & 867 \\
Waxman & 3784 & 17.4 & 658 & 573
\end{tabular}

Figure 2 illustrates the generating capacity of each technology in the base case. The least-cost framework projects an increase in new coal plant construction beginning in 2025 (no carbon constraint assumed), a gradual retirement of nuclear units, and rapid expansion of on-shore wind power plants and gas-fired combustion turbines.

\footnotetext{
${ }^{18}$ Hydropower is subtracted from these data, but power from small generators is not. The "Effective RES" column is reduced to account for the small-utility exemption.
} 


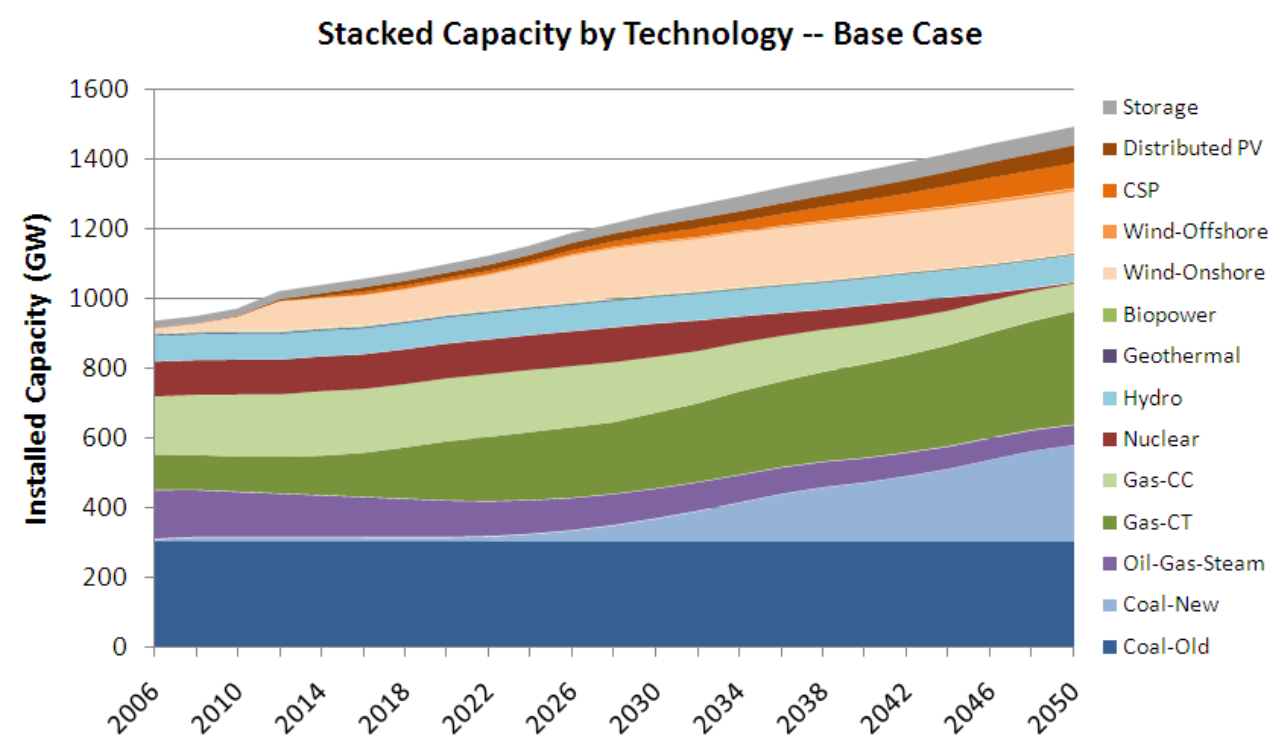

Figure 2. Electricity-generating capacity by technology in the base case

Figure 3 shows the amount of generation that each of the technologies provides through 2050. New coal plants provide most of the new generation, with wind and other renewable sources accounting for marginal additions as well.

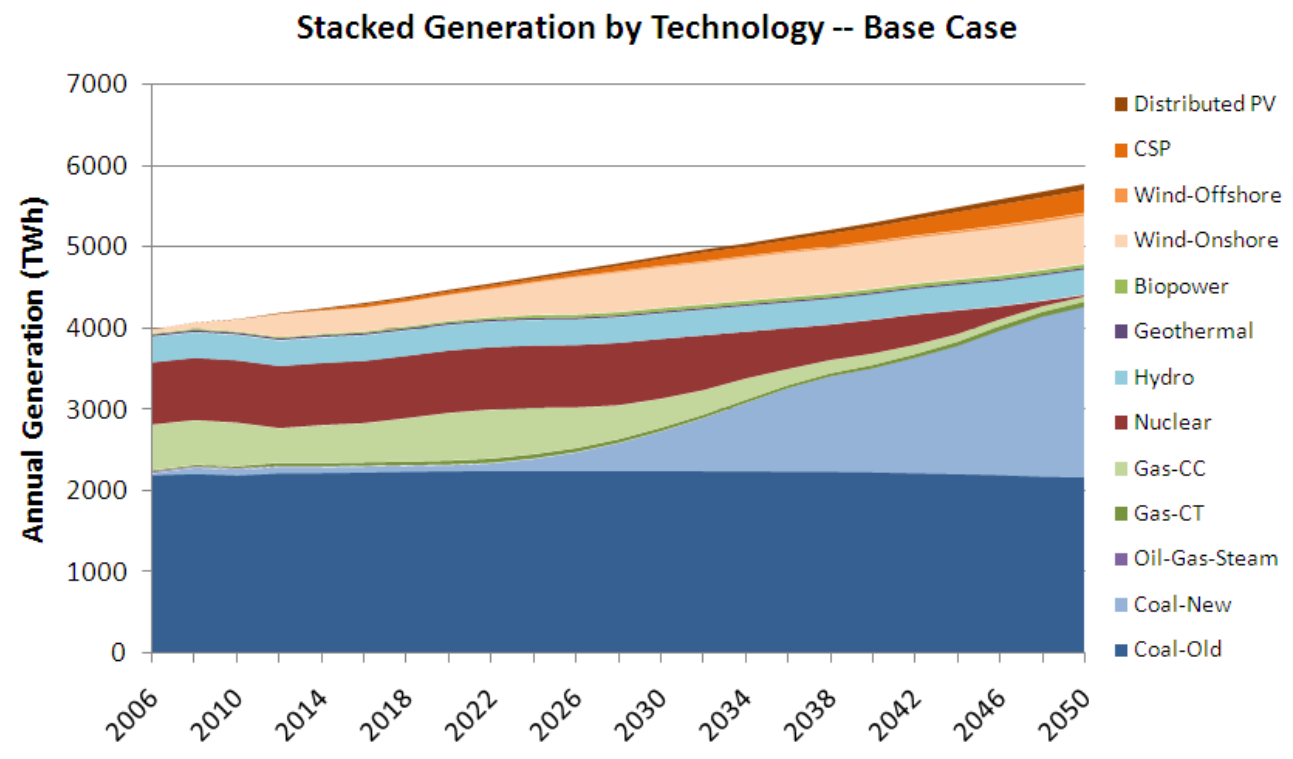

Figure 3. Electricity generation by technology in the base case

Figure 4 illustrates the least-cost installed generating capacity and electricity generation in 2030, according to technology type in each of the scenarios. Hydroelectric and nuclear capacities are unchanged between the base case and other scenarios-hydroelectric, 
because new capacity is not considered; nuclear because, with the higher costs, new capacity was not sufficiently attractive.
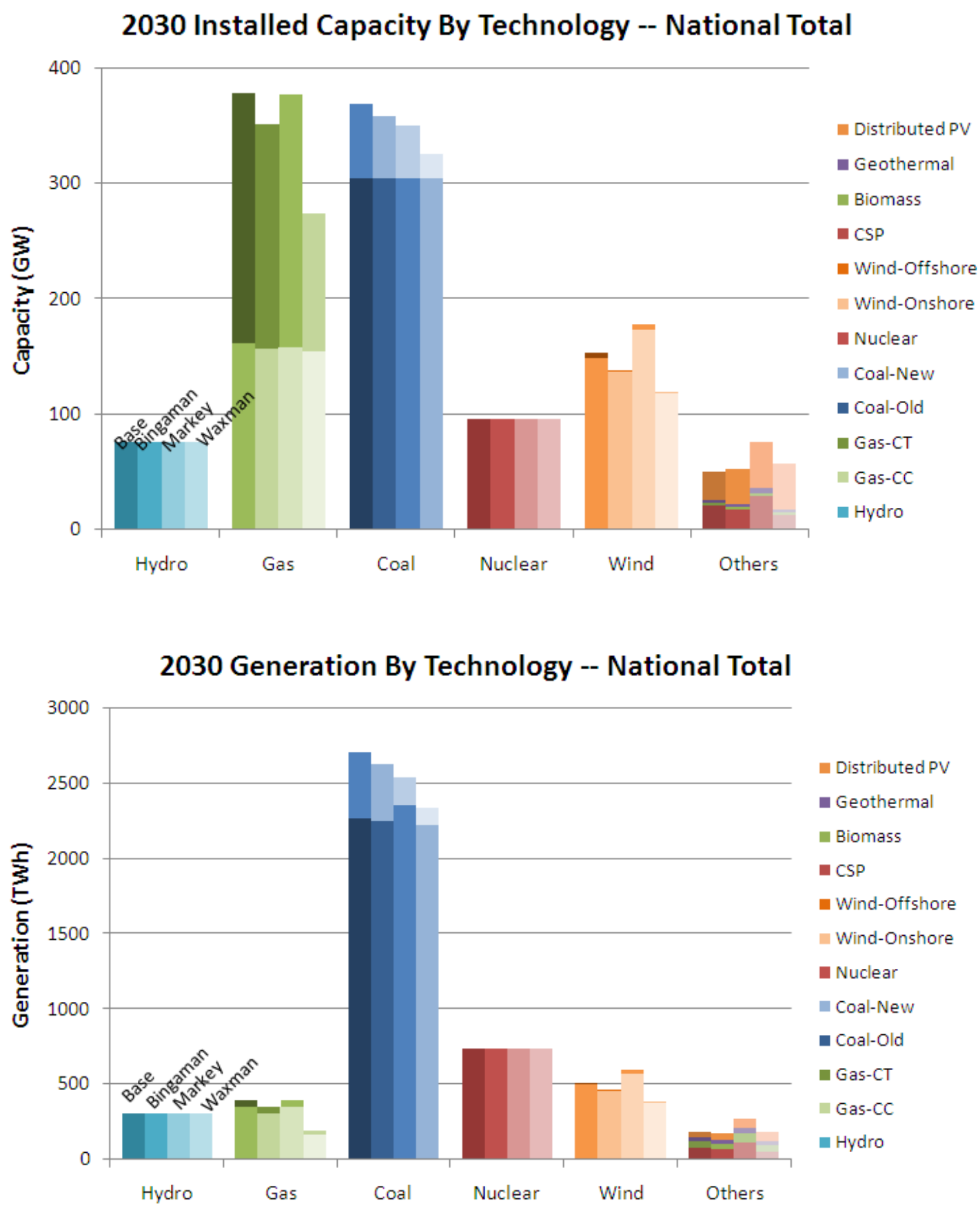

Figure 4. Generating capacity and electricity generation in 2030 in each of the scenarios

The Markey RES: The Markey RES is the most straightforward of the scenarios because it has no efficiency component. In that scenario, the additional renewable generation largely displaces coal while natural gas capacity and generation remain fairly constant 
from the base case. All renewable technologies increase over the base case-most notably wind with its additional $25 \mathrm{GW}$ of capacity by 2030 . Table 4 summarizes the capacity figures in the base case and RES cases.

Table 4. 2030 Capacity (GW) by Technology

\begin{tabular}{lrrrr} 
& Base & Bingaman & Markey & Waxman \\
\hline Gas & 379 & 352 & 378 & 274 \\
Coal & 370 & 359 & 350 & 326 \\
$\quad$ Biomass co-fire-ready coal ${ }^{*}$ & 27 & 25 & 48 & 42 \\
Nuclear & 96 & 96 & 96 & 96 \\
Hydropower & 76 & 76 & 76 & 76 \\
Wind & 153 & 139 & 178 & 120 \\
CSP & 21 & 18 & 30 & 13 \\
Distributed PV & 25 & 31 & 39 & 39 \\
Geothermal & 3 & 3 & 5 & 3 \\
Biopower & 2 & 2 & 2 & 2 \\
$\quad$ Qualifying Renewable Total & 208 & 197 & 261 & 183
\end{tabular}

* Biomass co-fire-ready coal capacity is included in the total coal capacity. Only $15 \%$ of this capacity is included in the qualifying renewable total row.

The Bingaman RES: The Bingaman RES - with an efficiency allowance that reduces overall electricity demand and a less-aggressive standard than the other bills - has a different effect on the generation mix than the Markey RES. Due to the reduced load, renewable capacity and generation both decline compared to the base case. The various exemptions and reductions applied to the original $20 \%$ target allow the RES requirement to be met in 2022 with only $10.3 \%$ of non-hydropower generation derived from renewable sources. ${ }^{19}$ As a result, wind and CSP capacity are, in fact, lower in 2030 in the Bingaman case than in the base case. Similarly, both coal and gas see mild reductions in the Bingaman case.

The Waxman RES: Adding an assumed 15\% demand-reduction requirement alongside the Waxman RES results in the most aggressive displacements of coal and gas generation. Consequently, there are large reductions in $\mathrm{CO}_{2}$ emissions. On the other hand, because the RES is now acting on a smaller amount of total generation, it is smaller in terms of megawatt hours. Therefore, there is less renewable capacity in the Waxman case than in the Markey or base cases. The steep decline in CSP capacity may be attributed to the fact that both distributed PV and CSP provide most of their output during the afternoon time-slice. There is a considerable amount of PV serving this time-slice based on the exogenously determined levels of distributed PV.

\footnotetext{
${ }^{19} 20 \%$ is reduced to $\sim 17 \%$ through the small-utility exemption. The efficiency component reduces that by a further $25 \%$, to $11.7 \%$. Distributed PV supplies $0.77 \%$ of eligible load, for which it gets triple credit, an effective $2.3 \%$. The $9.7 \%$ from central renewables plus $2.3 \%$ from distributed PV exceeds the required $11.7 \%$.
} 
Wind Capacity: Wind capacity expansion projections for the four scenarios are shown in Figure 5. The rapid expansion through 2012 is a direct result of the PTC, recently extended through that year; and the abrupt drop-off in 2014 is due to the expiration of that credit. Post PTC, the base, Bingaman, and Waxman RES cases allow slow wind growth until the mid 2020s when wind becomes economically competitive again - this time without the national PTC incentive.

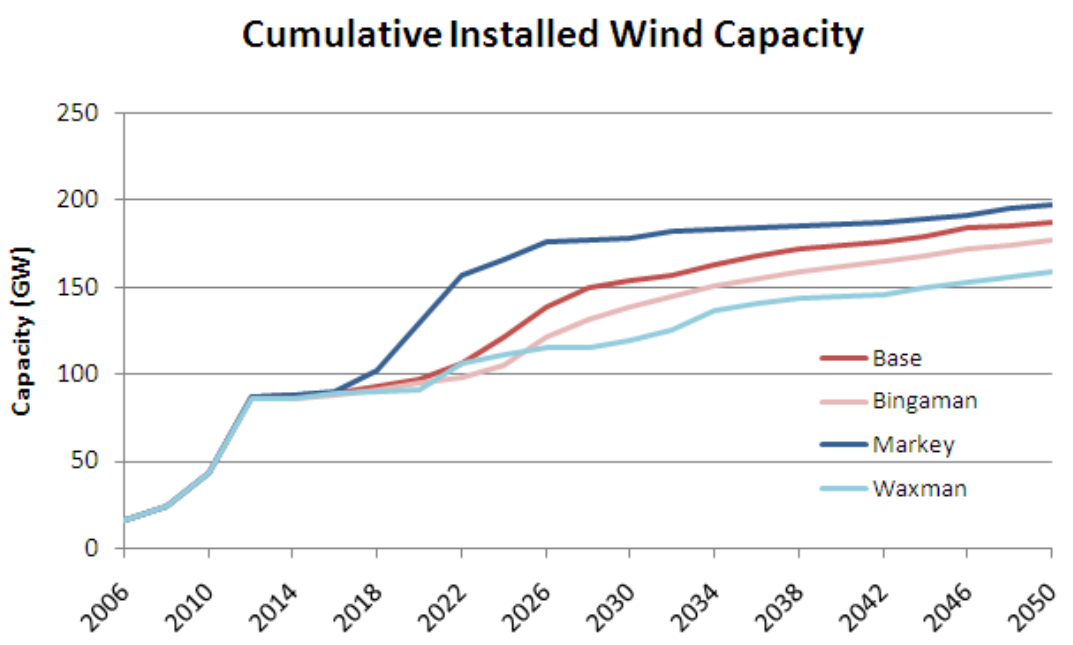

Annual Wind Capacity Installations

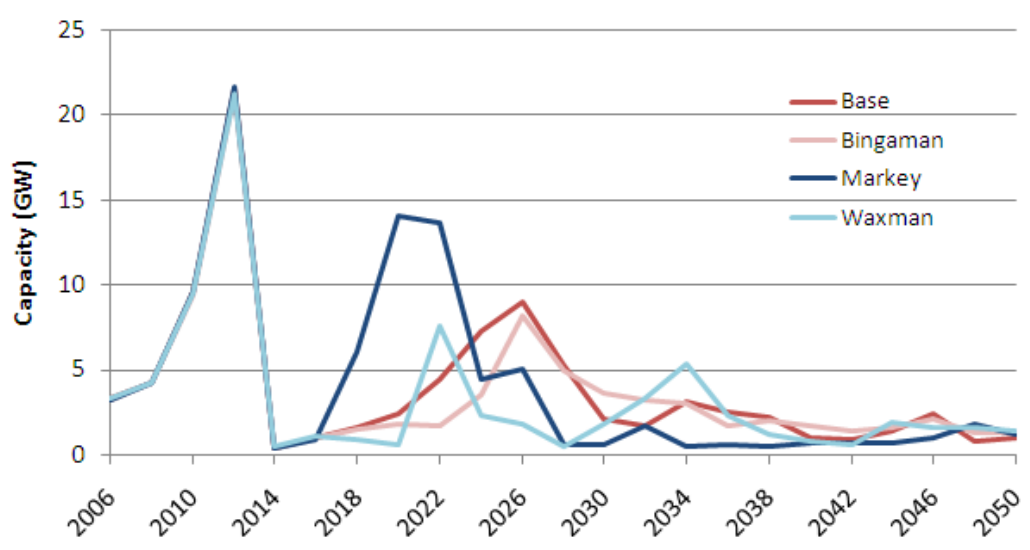

Figure 5. Cumulative and annual installations of wind power

In the Bingaman case, wind builds in the 2020s are not being driven by the RES, but by favorable economics: Renewable generation exceeds the RES after 2024. Under the Markey case, the renewable standard becomes binding again in 2018, encouraging wind project construction to resume earlier than in the base case. Once the RES is fully implemented, in 2026, wind installations drop again. In the later years of the model simulation, the base, Bingaman, and Waxman cases build more new wind than the Markey case-likely because, in the latter, those attractive sites that would have been 
economically viable in the 2040s were built in the 2020s to meet the RES instead. Thus, the gaps in total wind installations among the various scenarios shrink after 2030.

Carbon Dioxide Emissions: As shown in Figure 6, carbon dioxide $\left(\mathrm{CO}_{2}\right)$ emissions under the Bingaman RES decline by about 95 million metric tons (out of nearly 3,000 MMT) annually in 2030, compared to the base case. The Markey RES case results in slightly higher annual reductions in 2030, roughly $150 \mathrm{MMT}$. The Waxman scenario estimates annual $\mathrm{CO}_{2}$ reductions in 2030 of approximately $435 \mathrm{MMT}$; much of this reduction is due to the assumption that national electricity demand is $15 \%$ lower than in the base case because of the EERS. Cumulative $\mathrm{CO}_{2}$ emission reductions are shown in the bottom graph of Figure 6. The difference in cumulative $\mathrm{CO}_{2}$ emissions between the Waxman and base scenarios in 2030 is more than 5,000 MMT.

\section{Annual CO2 Emissions}

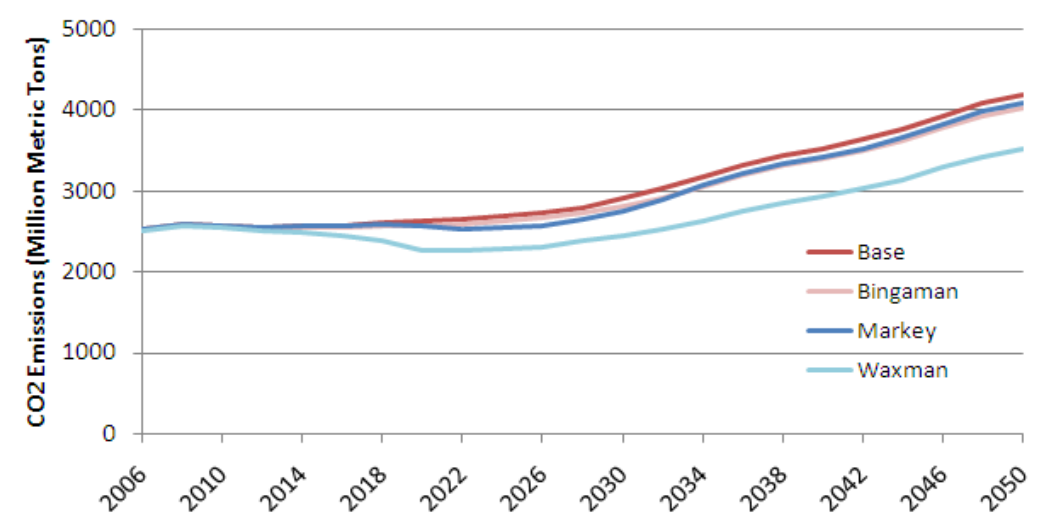

\section{Cumulative CO2 Reduction}

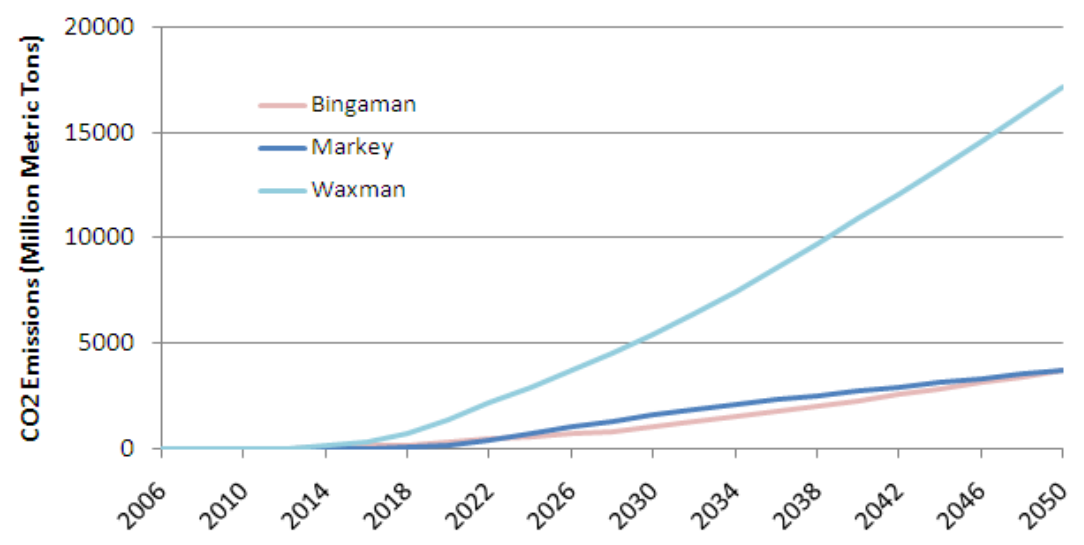

Figure 6. Annual and cumulative changes in $\mathrm{CO}_{2}$ emissions among the scenarios

Price Impacts: The impact of the scenarios on average national electricity prices is shown in Figure 7. Differences among the base case and the Bingaman or Markey scenarios are very small (less than 1\%). This is expected for the Bingaman RES because 
it is a small departure from the base case. For the Markey RES, however, there is substantial additional renewable capacity signifying increased capital costs for the overall system. Offsetting the capital increases are decreases in operational costs as the lowmarginal-cost renewable technologies displace coal, which results in fuel cost savings.

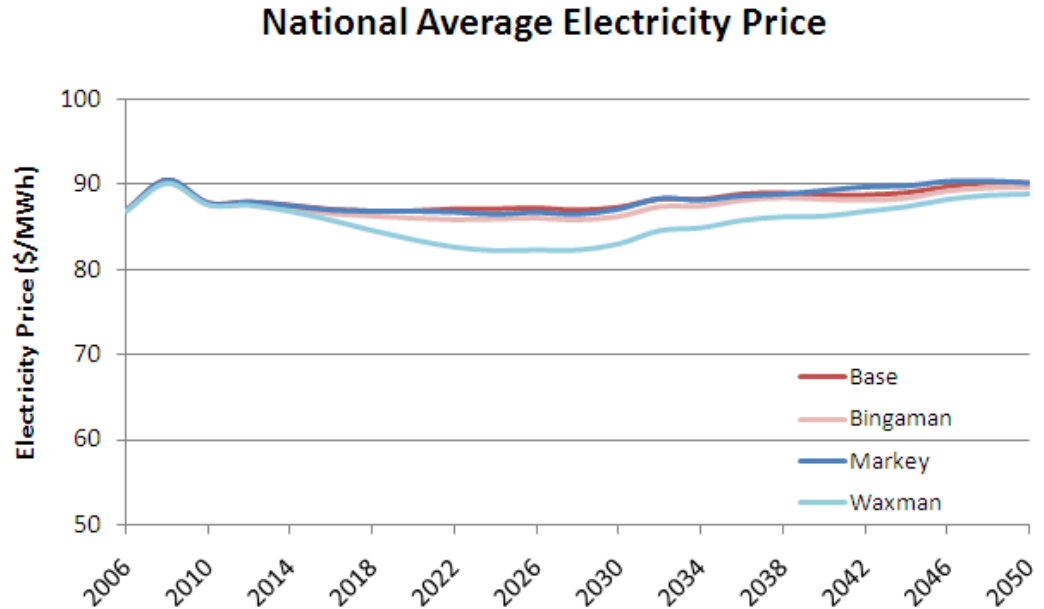

Figure 7. Preliminary assessment of RES on average national electricity prices

The analysis explicitly accounts for demand elasticity, and the reduction in coal demand means a reduction in coal prices, compounding the savings. To account for efficiency savings, we made the simplifying assumption that investments to improve energy efficiency and lower electricity demand did not affect the price of electricity. Thus, the Waxman case, with its $15 \%$ reduction in total load, has a noticeably lower electricity price, reaching about $5 \%$ below the other scenarios in the mid-2020s. In this scenario, less new capacity needs to be built and operated to supply the load; but, again, we did not consider any costs for the energy efficiency measures required to achieve the electricity savings.

The analysis also considers the impact of the proposed RES legislation on state-level electricity prices. Figure 8 shows that in the Markey scenario in 2022, more states see a reduction in calculated electricity prices than an increase compared to the base case. This scenario is chosen in isolation from the others because it has the greatest impact on renewable energy, and thus represents the largest price impacts. No state sees an increase in calculated electricity prices of greater than $5 \%$ in 2022, the year of peak increase in new renewable demand in that scenario. States that see the largest increases in calculated prices are generally those that have electricity prices significantly below the national average. It is important to note that data in this figure represent a snapshot at one point in time. Additionally, the model may skew results in states where a large portion of electricity is traded across borders, such as in the Pacific Northwest. 


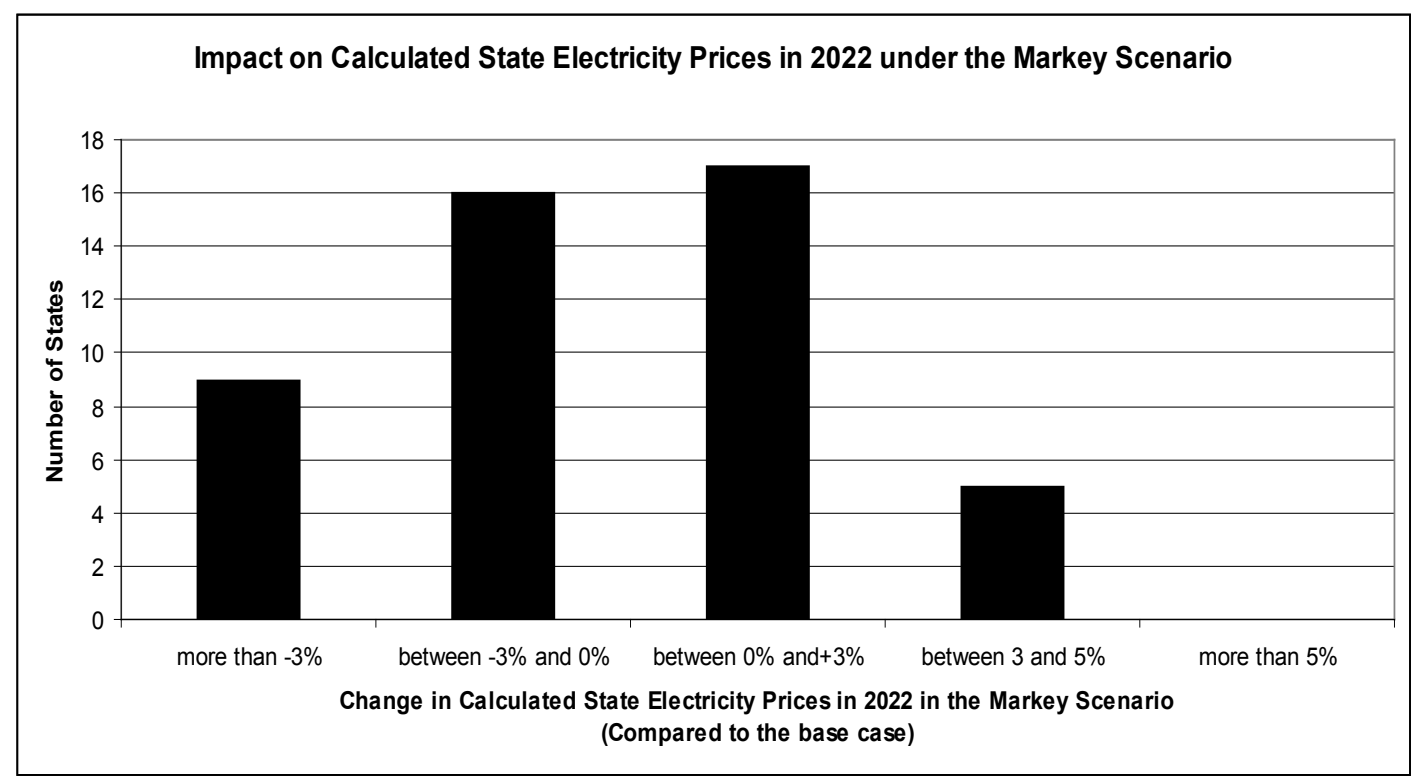

Figure 8. Impact of Markey scenario on state electricity prices in 2022

Figure 9 shows an estimated price of federal RECs during each time period. The model derives the estimate by tracking the marginal cost of generating the last unit of qualifying renewable power when the RES target is met. All REC prices are zero before 2016 and after 2032. The analysis does not consider transaction costs, which results in assumed "frictionless" trading of RECs among utilities. Based on these assumptions, REC prices are forecasted to peak in 2022 in the Waxman case at just less than $\$ 25 / \mathrm{MWh}$, or 2.5 cents/kWh; and in the Markey case, at $\$ 15 / \mathrm{MWh}$, or about 1.5 cents/kWh. In the Bingaman case, REC prices remain at zero through the analysis because the legislation would not require any new renewable sources, based on the assumptions used. Realworld conditions would likely result in higher REC prices. Note that REC prices in all years are lower than the alternative compliance payment, reinforcing the assertion that the ACP option is never taken in these scenarios.

\section{Simulated National REC Price}

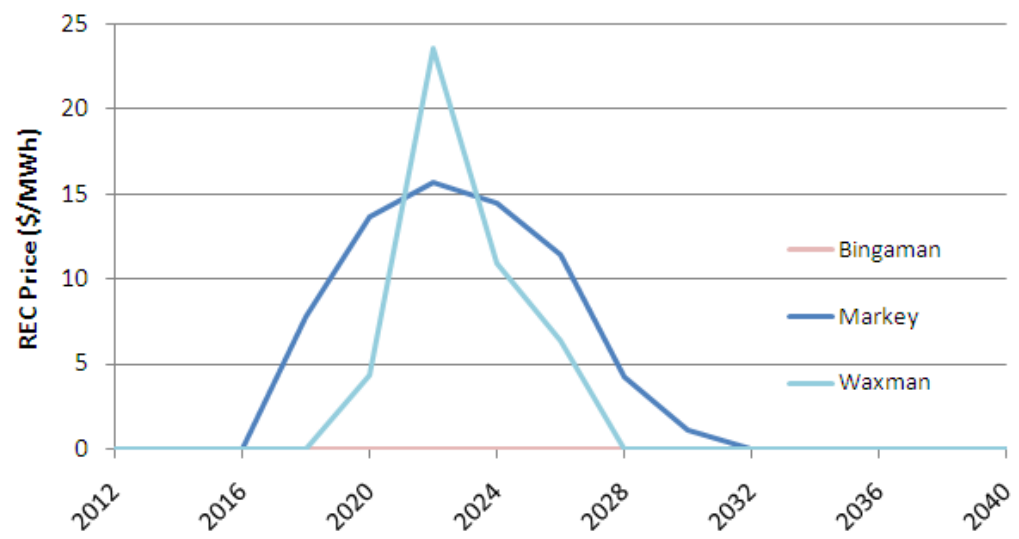

Figure 9. Simulated national price of renewable energy credits 
Geographical Differences: Data in Appendix B summarize the calculated impacts, at the state level, of the Markey RES legislation. We present the Markey results here because that legislation mandates greater use of renewables than any of the other bills. The table shows the amount of renewable energy generation that comes from wind, solar, biomass, and geothermal.

In summary, the western half of the country provides more than its share of renewable electricity, and is positioned to sell RECs to other states that opt not to meet the RES with their own generation. Obligated electricity suppliers that meet less than their RES requirements need to either purchase RECs from utilities in other states or pay an alternative compliance payment. In general, our modeling results indicate that it is more cost-effective for many of the southeastern states, in particular, to purchase low-cost RECs on the national market than to construct their own renewable energy generation sources. All states in the Southeast use biopower to some extent, either through co-firing at coal plants or dedicated biomass plants. Other studies suggest that this region has more cost-effective renewable resources than traditionally acknowledged. ${ }^{20}$

This analysis simulates the least-cost construction of new electricity transmission lines as needed during the capacity build-outs. This build-out allows transfer of electricity (notably, variable generation from renewables) to other regions of the country, although energy transfers would not necessarily occur directly between the West and Southeast. Rather, utilities in the Southeast would likely purchase only the RECs from projects in the West and other regions.

Based on data in Appendix B, Texas, California, Indiana, and Michigan each construct more than $10 \mathrm{GW}$ of wind capacity in the Markey RES case, while New York, Pennsylvania, Nebraska, New Hampshire, Iowa, the Dakotas, Oklahoma, Idaho, New Mexico, Oregon, and Washington are projected to see rapid expansion as well.

Finally, Appendix B also illustrates calculated solar power (PV and concentrating solar power) generation in the Markey case. Again, ReEDS did not calculate PV deployment endogenously in these scenarios, but instead used the UCS forecast at the NERC region/subregion level. Because California is one of the NERC regions/subregions for which external estimates of distributed PV were available, its large deployment of distributed PV was entirely exogenously specified. For other states such as Texas, Nevada, North Carolina, and New Jersey, ReEDS allocated a significant portion of the distributed PV from their NERC region/subregion to them because of the favorable distributed-PV economics in those states relative to other states in the same NERC regions/subregions.

Modeling Conclusions: In summary, the Bingaman RES case has only a minor impact on the national electricity sector because it requires no increase in renewable generation

\footnotetext{
${ }^{20}$ See, for example, "Local Clean Power," World Resources Institute, April 2009; or "Yes We Can: Southern Solutions for a National Renewable Energy Standard," presentation from Southern Alliance for Clean Energy, February 12, 2009, at http://www.cleanenergy.org/images/files/SERenewables022309rev.pdf.
} 
over the base case in 2021, according to the assumptions used. The Markey RES legislation requires significantly greater renewable power deployment and the construction of new transmission infrastructure in a timely manner. The Waxman RES lies between the two, encouraging a significantly higher proportion of renewable energy than Bingaman, but less in absolute terms than Markey; this is due to the assumption that energy efficiency would play a more prominent role. The state and regional impacts will depend, to a significant extent, on whether this new transmission capacity can be deployed without delay. Although the assumptions used in this analysis show that it is, on balance, usually less costly for the southeastern region to purchase RECs than to build their own generation, some states in and near the region do have significant renewable supply to contribute, at least in the Markey scenario. Texas develops both wind and solar; Florida, solar; North Carolina, solar; many states, biopower.

\section{Potential Follow-on Work}

Potential follow-on work for this analysis could include:

- Conducting sensitivity analysis on the RES legislation. Key sensitivities that could be considered include different energy efficiency allowance penetrations, gas price trajectories, power plant costs, RE technology improvements over time, and policy assumptions on PTC extensions and/or carbon caps/taxes. Additionally, it might be useful to explore the extent to which excess federal RECs, accrued as a result of state RES compliance, are retired rather than sold.

- Comparing past and ongoing work. Several other organizations - including the Union of Concerned Scientists, the Energy Information Administration, and Lawrence Berkeley National Laboratory-have published findings from similar RES analyses. Follow-on work could include more comprehensive comparisons of these findings with those from other organizations.

- Analyzing proposed RES legislation in combination with other climate and energy policies. In addition to the RES proposed in the Waxman discussion draft, the bill also includes a national cap-and-trade system to mitigate greenhouse gases as well as many other energy measures. Follow-on analysis will evaluate the combined impacts of the RES and cap-and-trade policies on the electricity sector. NREL's methodological framework offers advantages by simulating renewable electric technologies at a level of detail not yet available in other models. However, it is important to note that the NREL model is not economy-wide, nor does it handle feedback effects in as detailed a manner as some general equilibrium models. This type of analysis could still provide useful insights into how the electricity sector is impacted by overlapping energy and climate policies. 


\section{REC Market Design Issues in the Proposed Legislation}

This section compares the REC market design and implementation features of the Bingaman, Markey, and Waxman bills. Based on our analysis, both the Waxman and Markey bills are clearer than the Bingaman discussion draft ${ }^{21}$ on the issue of REC market design and state RES interactions and, thus, may be easier to implement. However, all of the bills raise some questions regarding the issuance and treatment of RECs and the interaction with existing state RES policies. Table 5 summarizes key differences in policy design and REC market issues in the bills.

Table 5. Key Differences in REC Market Issues in the Three Proposed RES Bills

\begin{tabular}{|c|c|c|c|}
\hline Issue & Bingaman & Markey & Waxman \\
\hline $\begin{array}{l}\text { Definition of a } \\
\text { federal REC }\end{array}$ & Not defined & $\begin{array}{l}\text { Federal REC "means a credit, } \\
\text { representing one kWh of } \\
\text { renewable electricity" }\end{array}$ & $\begin{array}{l}\text { Federal REC "means a credit, } \\
\text { representing one MWh of } \\
\text { renewable electricity" with } \\
\text { unique serial number }\end{array}$ \\
\hline $\begin{array}{l}\text { REC Tracking } \\
\text { Systems }\end{array}$ & $\begin{array}{l}\text { Calls for federal "trading" } \\
\text { systems; silent on use of } \\
\text { existing tracking systems }\end{array}$ & $\begin{array}{l}\text { "Rely upon" existing state/regional } \\
\text { REC tracking systems }\end{array}$ & $\begin{array}{l}\text { "Rely upon" existing } \\
\text { state/regional REC tracking } \\
\text { systems }\end{array}$ \\
\hline $\begin{array}{l}\text { REC Market } \\
\text { Administrator }\end{array}$ & $\begin{array}{l}\text { "An appropriate market- } \\
\text { making entity" }\end{array}$ & $\begin{array}{l}\text { Authority can be delegated by DOE } \\
\text { to existing "market-making } \\
\text { entities... for purposes of creating } \\
\text { a transparent and efficient national } \\
\text { market"; FERC given oversight }\end{array}$ & Not addressed \\
\hline $\begin{array}{l}\text { Issuance of } \\
\text { Federal RECs }\end{array}$ & $\begin{array}{l}\text { Issued to generators. Issued } \\
\text { to utilities if complied with } \\
\text { state RES, or paid state } \\
\text { ACP, or other fees. For } \\
\text { existing power contracts, } \\
\text { retail electric provider gets } \\
\text { credit. Language unclear. }\end{array}$ & $\begin{array}{l}\text { Issued to generators. Exceptions } \\
\text { for states with central RES } \\
\text { procurement and, in some cases, } \\
\text { for state ACP payments. For } \\
\text { existing power contracts with retail } \\
\text { electricity provider, provider gets } \\
\text { credit. }\end{array}$ & $\begin{array}{l}\text { Issued to generators. Exceptions } \\
\text { for states with central RES } \\
\text { procurement and, in some } \\
\text { cases, for state ACP payments. } \\
\text { For existing power contracts with } \\
\text { retail electricity provider, provider } \\
\text { gets credit. }\end{array}$ \\
\hline Banking Allowed & 3 Years & 3 years & 3 years \\
\hline $\begin{array}{l}\text { Provisions for } \\
\text { "Excess" Federal } \\
\text { RECs (if state } \\
\text { target is higher) }\end{array}$ & $\begin{array}{l}\text { Silent on issue (or covered } \\
\text { by general state saving } \\
\text { clause) }\end{array}$ & $\begin{array}{l}\text { States have authority to determine } \\
\text { whether excess state RECs can be } \\
\text { used for federal compliance in } \\
\text { other states }\end{array}$ & $\begin{array}{l}\text { States have authority to } \\
\text { determine whether excess state } \\
\text { RECs can be used for federal } \\
\text { compliance in other states }\end{array}$ \\
\hline $\begin{array}{l}\text { Voluntary Green } \\
\text { Power }\end{array}$ & Not specifically addressed & Not specifically addressed & Not specifically addressed \\
\hline $\begin{array}{l}\text { Alternative } \\
\text { Compliance } \\
\text { Payment (ACP) }\end{array}$ & $3 \phi / k w h$ (inflation adjusted) & $\begin{array}{l}\text { Lesser of: } 5 \phi / \mathrm{kwh} \text { (inflation } \\
\text { adjusted) or } 200 \% \text { of prior year } \\
\text { average market value of federal } \\
\text { RECs }\end{array}$ & $\begin{array}{l}\text { Lesser of: } 5 \phi / \mathrm{kwh} \text { (inflation } \\
\text { adjusted) or } 200 \% \text { of average } \\
\text { market value of federal RECs for } \\
\text { previous compliance period }\end{array}$ \\
\hline $\begin{array}{l}\text { Use of ACP } \\
\text { Revenues }\end{array}$ & $\begin{array}{l}\text { Allocated to state energy } \\
\text { offices with preference to } \\
\text { states with small share of } \\
\text { economic RE capacity }\end{array}$ & $\begin{array}{l}\text { Returned proportionately to all } \\
\text { utilities that met federal } \\
\text { requirement }\end{array}$ & $\begin{array}{l}\text { Returned proportionately to all } \\
\text { utilities that met federal } \\
\text { requirement }\end{array}$ \\
\hline $\begin{array}{l}\text { State/federal } \\
\text { penalties }\end{array}$ & $\begin{array}{l}\text { Federal penalties reduced } \\
\text { by state penalties paid if } \\
\text { state RES is higher }\end{array}$ & $\begin{array}{l}\text { Federal penalties not reduced by } \\
\text { state penalties }\end{array}$ & $\begin{array}{l}\text { Federal penalties not reduced by } \\
\text { state penalties }\end{array}$ \\
\hline
\end{tabular}

\footnotetext{
${ }^{21}$ Issues related to the Bingaman RES policy design and REC market were discussed in an earlier NREL report, "Evaluating a Proposed 20\% National Renewable Portfolio Standard," http:/www.nrel.gov/docs/fy09osti/45161.pdf
} 
Dual RECs System: All three proposed bills create a dual RECs system, with federal RECs separate from state renewable electricity standard RECs. While this method may be required, based on other elements of the legislation, it may also create tracking problems and confusion over appropriate claims, because there could be two RECs (federal and state) issued for a single megawatt hour of renewable generation. Because state RECs generally specify that they contain renewable energy attributes and establish a basis for claiming renewable energy, the federal REC cannot also contain these attributes.

To accommodate the presence of both federal RECs and state RECs, the federal REC would need to be defined in a way to avoid confusion (e.g., for federal RES compliance purposes only). Another option for addressing potential confusion with state REC programs is to adopt a single RECs system, or require that federal RECs travel with and remain bundled with any available state RECs; however, this approach is not used in any of the three bills.

State RES Interaction: All of the bills call for preserving the integrity of existing state RES standards, although the Markey and Waxman bills contain more specific language to that effect. One key issue is whether state RES standards can be more stringent than the federal standard. For example, utilities in states with higher RES targets than the federal target in a given year may be allowed to sell "excess" RECs to utilities in other states for federal compliance. If this is allowed, state targets would not necessarily be more stringent than the federal RES. Both the Markey and Waxman bills include language that gives states the authority to decide how to address this issue. The Bingaman bill is less clear and includes only a generic state savings clause that does not directly address the issue. Other approaches that could be used to address this issue (but not included in any of the bills) would be to either: 1) directly ensure that utilities are not able to trade federal RECs that are used to meet a higher state RES standard, or 2) adjust the utility's federal requirement to be the greater of the state requirement, or the level required under federal law.

Similarly, small utilities that are exempted from the federal RES - but that are subject to state RES policies - could also sell RECs they use for state compliance to entities in other states for federal compliance, unless precluded from doing so at the state level. Again, this would mean that state standards would not, absent state policy precluding the sale of excess federal RES, be additional to the federal standard.

Distributed Generation and Tribal Credit Multipliers: All three bills call for the issuance of three federal renewable energy credits (RECs) for each kilowatt hour of renewable electricity generated by distributed generation facilities. Bingaman also calls for the issuance of two federal renewable energy credits (RECs) for each kilowatt hour of renewable electricity generated on tribal lands. It would be preferable to issue a single REC for each megawatt hour of generation from these applications, and provide "triple federal compliance credit" for distributed generation sources, and double federal compliance credit for projects on tribal lands. It would create confusion in the marketplace and tracking difficulties to issue multiple RECs for the same megawatt hour of generation. For this reason, states that have developed credit multipliers have not 
actually provided multiple RECs for each MWh of generation; instead, each such REC that is retired is deemed to count toward a utility's RES obligation based on the multiplier value.

Definition of REC: The Waxman bill defines a federal renewable electricity credit as a credit that represents $1 \mathrm{MWh}$ of renewable electricity; Markey defines a REC as $1 \mathrm{kWh}$ of renewable electricity. The Bingaman bill does not explicitly define a REC, but describes it in kilowatt hours throughout the text. REC tracking systems and state RES policies define RECs as $1 \mathrm{MWh}$ of renewable electricity, rather than $1 \mathrm{kWh}$. For consistency, it would be preferable to use the same units currently used by states and tracking systems. As discussed above, under a dual state-federal RECs system, it is also important that the renewable and environmental "attributes" travel with the state REC the federal REC should only be a compliance demonstration tool.

Nontradability of RECs from Existing Renewable Generation: The Bingaman bill establishes nontradable RECs for existing generation that would likely pose implementation challenges. This provision is not included in either the Markey or Waxman bills. The nontradability of RECs from existing generators could pose problems because generators that came online prior to 2006 may have already traded their state RECs (and potentially any future federal RECs) in transactions conducted for state RES compliance. Under the draft legislation, these purchases (because they are traded) may not count toward the federal RES. In addition, defining "nontradability" may be difficult given that RECs can be combined with electricity, and sold in various ways. Furthermore, the provision requires complicated regulatory processes to define incremental generation from existing renewable generation.

Alternative Compliance Payments: The Bingaman bill calls for an alternative compliance payment of 3 cents/kWh. The Waxman and Markey bills call for the ACP to be the lesser of 5 cents $/ \mathrm{kWh}$ or $200 \%$ of the average market value of federal RECs from the previous compliance period (Waxman) or prior year (Markey). By including the provision that the ACP may be based on prior market value, it would create some uncertainty in the market and would be more difficult to implement than simply having a fixed ACP payment.

All of the bills call for the federal government to issue federal RECs to retail electric suppliers making alternative compliance payments under certain defined circumstances. Because payments to state ACPs do not directly and immediately get translated to renewable megawatt hours, allocating federal RECs in this instance to the utility making the ACP payment will be a challenge. Additionally, by giving the federal REC to the utility, the generator is left with a state REC that does not include the federal REC. The generator, however, may already have sold its state REC to another party under a longterm contract. In states requiring that state RES policies be met by retiring both the state and federal REC, this generator will no longer be selling a state-qualifying REC. This issue could be addressed if federal RECs were only issued on the basis of eligible renewable generation and not ACP payments. 
Interaction with State Penalties: The Bingaman bill calls for state "penalties" to be deducted from the federal penalty, in cases where a utility is in noncompliance of both a state and federal RES, and the state RES requirement is "greater than" the federal RES. This provision is not included in the Markey or Waxman bills. This may be difficult to implement in practice because state and federal RES policies differ in many ways, not just the percentage obligation - it is not immediately clear on what basis "greater than" will be determined. In addition, states have developed a wide range of financial compliance mechanisms, not all of which may be classified as penalties per se.

Double-Counting: The double-counting language in all of the bills addresses only double-counting of the same megawatt hour for federal compliance. The potential gaming between federal RES compliance and voluntary sales is not directly addressed. This is potentially harmful to consumers who expect voluntary REC purchases to represent use of renewable power beyond what would have occurred without the voluntary purchase.

Renewable Electricity Deployment Fund Allocation: The Markey and Waxman bills call for distributing all federal ACPs and penalties to utilities in proportion to the share of federal RECs that those utilities have procured. The intent of this is likely to be rewarding those utilities that have complied with the federal RES, but it may not directly advance renewable energy project deployment. In contrast, the Bingaman bill calls for these funds to be directed to state energy offices to be used to support additional renewable energy development, with preference given to states with a small proportion of cost-effective renewables. 


\section{Appendix A - Attributes of Modeling Renewable Electricity: ReEDS vs. NEMS}

(Most important differences are in bold.)

\begin{tabular}{cl}
\multicolumn{1}{c}{ Attribute } & Details \\
\hline $\begin{array}{l}\text { Costs dominated by } \\
\text { capital costs }\end{array}$ & Finance, depreciation, materials costs, \\
\hline
\end{tabular}

ReEDS: Electric-Sector ONLY (Capacity Expansion Model)

capital costs

learning/decreasing costs

Operating costs are

fixed and small

Modular plant size

Environmental

impacts are generally

minimal

Resource sites vary in quality

Risks, variability

Reduces over/under capacity problems and transmission requirements

Air emissions, life-cycle analysis of materials

Resource level, time of availability, access to infrastructure, terrain

Conversion to usable

Transmission, siting

energy must occur

near resource site

Resource variability

Backup requirements, ancillary service requirements, curtailments, forecasting, diversity

Distributed capability - Competition at the retail level, solar, biomass, wind interaction with owner's loads

Immature industry
ReEDS base case capital costs are intended to

represent "mainstream" industry expectations

(largely from Black and Veatch)

Does not address risk

Assumes all plants (including conventionals) can be built in a modular fashion

Includes air emissions

Models resource site-quality issues at relatively fine geographic resolution (more than 350 regions); models use of existing grid and new transmission construction necessary to obtain resource

High spatial resolution enables relatively detailed modeling of transmission and siting (see above)

Represents variability and diversity through stochastic treatment of capacity value, operating reserve requirements, and curtailments.

Can allocate exogenous estimates of distributed PV at the 13 NERC region/subregion level to ReEDS 134 balancing areas based on distributed PV economics and resource

Includes learning.

Includes growth penalties (rapid growth causes price increases)
NEMS: ALL Energy Sectors (Energy-Economic Model - EMM

EIA staff draws on various sources of expert opinion

to select capital cost assumptions

Does not address risk

Assumes all plants (including conventionals) can be built in a modular fashion

Includes air emissions

Applies long-term multipliers, based in part on geospatial analysis of access to infrastructure and, in part, on expert judgment. Geographic resolution at NEMS region level (13). Due to coarse geographic resolution, only four new transmission lines are considered, and their use is limited to new generators

Transmission cost is represented by a regional adder to the cost of every KWh (e.g., wind transmission cost is same as gas-fired power transmission cost with the exception noted immediately above)

Represents variability in resource and has some decrease in capacity value as a function of amount of wind installed, but not as a function of diversity

Represents load at the 13 region levels of the EMM and distributed $\mathrm{PV}$.

Includes learning.

Includes growth penalties. uncertainty in future cost and performance, supply/demand imbalances 


\section{Appendix B - State-Level 2030 Renewable Generation Totals from Markey Scenario (TWh)}

\begin{tabular}{lrrrrlrrrr} 
& Wind & Solar & Bio & Geo & & Wind & Solar & Bio & Geo \\
\hline Alabama & 0.0 & 0.0 & 1.4 & 0.0 & Nebraska & 10.6 & 0.4 & 0.2 & 0.0 \\
Arizona & 13.8 & 2.0 & 0.0 & 0.0 & Nevada & 15.0 & 7.7 & 0.0 & 2.0 \\
Arkansas & 0.4 & 0.0 & 0.7 & 0.0 & New Hampshire & 2.6 & 0.8 & 0.6 & 0.0 \\
California & 78.1 & 112.2 & 3.8 & 39.6 & New Jersey & 22.4 & 5.2 & 0.6 & 0.0 \\
Colorado & 9.9 & 0.3 & 0.1 & 0.0 & New Mexico & 16.0 & 1.3 & 0.1 & 0.0 \\
Connecticut & 7.0 & 0.8 & 0.8 & 0.0 & New York & 7.0 & 3.1 & 0.2 & 0.0 \\
Delaware & 1.3 & 0.3 & 0.0 & 0.0 & North Carolina & 10.8 & 7.0 & 7.0 & 0.0 \\
Florida & 2.9 & 3.2 & 11.0 & 0.0 & North Dakota & 6.4 & 0.0 & 0.6 & 0.0 \\
Georgia & 2.1 & 0.0 & 1.6 & 0.0 & Ohio & 18.1 & 0.5 & 1.3 & 0.0 \\
Idaho & 9.2 & 0.0 & 0.1 & 0.0 & Oklahoma & 20.5 & 0.0 & 1.5 & 0.0 \\
Illinois & 19.4 & 1.4 & 0.7 & 0.0 & Oregon & 21.7 & 0.0 & 0.3 & 0.0 \\
Indiana & 18.1 & 1.7 & 0.6 & 0.0 & Pennsylvania & 30.4 & 0.0 & 1.1 & 0.0 \\
lowa & 15.5 & 0.2 & 0.3 & 0.0 & Rhode Island & 2.2 & 0.0 & 0.0 & 0.0 \\
Kansas & 12.2 & 1.0 & 1.3 & 0.0 & South Carolina & 0.4 & 1.5 & 2.2 & 0.0 \\
Kentucky & 1.7 & 0.9 & 0.8 & 0.0 & South Dakota & 4.8 & 0.0 & 0.2 & 0.0 \\
Louisiana & 3.9 & 2.8 & 0.7 & 0.0 & Tennessee & 1.0 & 0.0 & 1.5 & 0.0 \\
Maine & 4.1 & 0.0 & 1.4 & 0.0 & Texas & 56.6 & 13.9 & 4.6 & 0.0 \\
Maryland & 9.0 & 0.0 & 0.3 & 0.0 & Utah & 11.9 & 0.3 & 0.0 & 0.5 \\
Massachusetts & 6.4 & 0.0 & 1.6 & 0.0 & Vermont & 2.1 & 0.1 & 0.4 & 0.0 \\
Michigan & 27.0 & 0.0 & 0.9 & 0.0 & Virginia & 2.5 & 1.7 & 1.4 & 0.0 \\
Minnesota & 35.6 & 0.3 & 0.6 & 0.0 & Washington & 14.5 & 2.0 & 1.1 & 0.0 \\
Mississippi & 0.0 & 0.0 & 1.2 & 0.0 & West Virginia & 1.6 & 0.0 & 0.4 & 0.0 \\
Missouri & 13.4 & 0.0 & 0.8 & 0.0 & Wisconsin & 12.8 & 0.0 & 0.9 & 0.0 \\
Montana & 6.3 & 0.4 & 0.0 & 0.0 & Wyoming & 5.2 & 0.0 & 0.0 & 0.0 \\
\hline & & & & & United States & 594.1 & 173.3 & 57.0 & 42.2
\end{tabular}




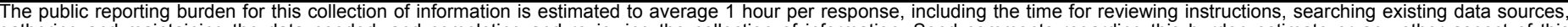

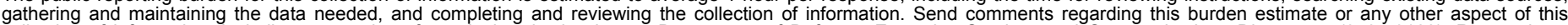

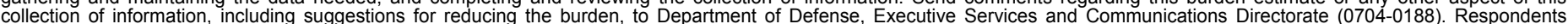

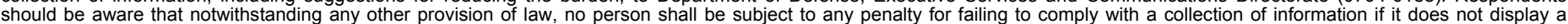

should be aware that notwithstanding

PLEASE DO NOT RETURN YOUR FORM TO THE ABOVE ORGANIZATION.

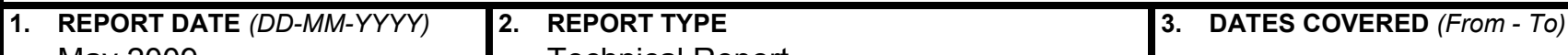
May 2009

Technical Report

4. TITLE AND SUBTITLE

Comparative Analysis of Three Proposed Federal Renewable

Electricity Standards 5a. CONTRACT NUMBER

DE-AC36-08-GO28308

5b. GRANT NUMBER

5c. PROGRAM ELEMENT NUMBER

5d. PROJECT NUMBER

NREL/TP-6A2-45877

5e. TASK NUMBER

SA07.9C50

5f. WORK UNIT NUMBER
7. PERFORMING ORGANIZATION NAME(S) AND ADDRESS(ES)

National Renewable Energy Laboratory

1617 Cole Blvd.

Golden, CO 80401-3393
8. PERFORMING ORGANIZATION REPORT NUMBER

NREL/TP-6A2-45877

9. SPONSORING/MONITORING AGENCY NAME(S) AND ADDRESS(ES)

10. SPONSOR/MONITOR'S ACRONYM(S)

NREL

11. SPONSORING/MONITORING AGENCY REPORT NUMBER

12. DISTRIBUTION AVAILABILITY STATEMENT

National Technical Information Service

U.S. Department of Commerce

5285 Port Royal Road

Springfield, VA 22161

13. SUPPLEMENTARY NOTES

\section{ABSTRACT (Maximum 200 Words)}

This paper analyzes potential impacts of proposed national renewable electricity standard (RES) legislation. An RES is a mandate requiring certain electricity retailers to provide a minimum share of their electricity sales from qualifying renewable power generation. The analysis focuses on draft bills introduced individually by Senator Jeff Bingaman and Representative Edward Markey, and jointly by Representative Henry Waxman and Markey. The analysis uses NREL's Regional Energy Deployment System (ReEDS) model to evaluate the impacts of the proposed RES requirements on the U.S. energy sector in four scenarios.

\section{SUBJECT TERMS}

NREL; renewable portfolio standard; RPS; Regional Energy Deployment System model; ReEDS; renewable energy certificates; RECs; generation capacity; National Energy Modeling System; NEMS; renewable electricity standard; RES

\begin{tabular}{|c|c|c|c|c|}
\hline 16. SECURITY & CLASSIFICATI & N OF: & 17. LIMITATION & 18. NUMBER \\
\hline $\begin{array}{l}\text { a. REPORT } \\
\text { Unclassified }\end{array}$ & $\begin{array}{l}\text { b. ABSTRACT } \\
\text { Unclassified }\end{array}$ & $\begin{array}{l}\text { c. THIS PAGE } \\
\text { Unclassified }\end{array}$ & $\begin{array}{l}\text { OF ABSTRACT } \\
\text { UL }\end{array}$ & \\
\hline
\end{tabular}

19a. NAME OF RESPONSIBLE PERSON

19b. TELEPHONE NUMBER (Include area code) 